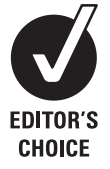

- Additional tables are published online only at http:// jech.bmj.com/content/vol63/ issue1

${ }^{1}$ Department of Geography, University of Durham, UK;

${ }^{2}$ Division of Public Health, University of Liverpool, UK;

${ }^{3}$ Department of Public Health, Erasmus MC, The Netherlands

Correspondence to:

Dr C Bambra, Department of Geography, Wolfson Research Institute, Queen's Campus,

Durham University, Stockton on Tees TS17 6BH, UK; clare. bambra@durham.ac.uk

Accepted 31 July 2008

Published Online First

3 September 2008

\title{
Gender, health inequalities and welfare state regimes: a cross-national study of 13 European countries
}

\author{
C Bambra, ${ }^{1}$ D Pope, ${ }^{2}$ V Swami, ${ }^{2}$ D Stanistreet, ${ }^{2}$ A Roskam, ${ }^{3}$ A Kunst, ${ }^{3}$ A Scott-Samuel ${ }^{2}$
}

\begin{abstract}
Background: This study is the first to examine the relationship between gender and self-assessed health $(\mathrm{SAH})$, and the extent to which this varies by socioeconomic position in different European welfare state regimes (Liberal, Corporatist, Social Democratic,

Southern).
\end{abstract}

Methods: The EUROTHINE harmonised data set (based on representative cross-sectional national health surveys conducted between 1998 and 2004) was used to analyse SAH differences by gender and socioeconomic position (educational rank) in different welfare states. The sample sizes ranged from 7124 (Germany) to 118245 (Italy) and concerned the adult population (aged $\geqslant 16$ years).

Results: Logistic regression analysis (adjusting for age) identified significant gender differences in SAH in nine European welfare states. In the UK (OR 0.88; $95 \% \mathrm{Cl} 0.78$ to 0.99 ) and Finland (OR 0.85; $95 \% \mathrm{Cl} 0.77$ to 0.95 ), men were significantly more likely to report "bad" or "very bad" health. In Denmark, Sweden, Norway, Holland, Italy, Spain and Portugal, a significantly higher proportion of women than men reported that their health was "bad" or "very bad". The increased risk of poor SAH experienced by women from these countries ranged from a $23 \%$ increase in Denmark (OR 1.23; $95 \% \mathrm{Cl} 1.08$ to 1.39 ) to more than a twofold increase in Portugal (OR 2.01; 95\% $\mathrm{Cl} 1.87$ to 2.15). For some countries (Italy, Portugal, Sweden), women's relatively worse SAH tended to be most prominent in the group with the highest level of education.

Discussion: Women in the Social Democratic and Southern welfare states were more likely to report worse SAH than men. In the Corporatist countries, there were no gender differences in SAH. There was no consistent welfare state regime patterning for gender differences in SAH by socioeconomic position. These findings constitute a challenge to regime theory and comparative social epidemiology to engage more with issues of gender.

Gender differences in health are well documented in terms of both mortality and morbidity. ${ }^{1}$ However, the extent to which gender differences in health vary by socioeconomic position is less well documented. ${ }^{2}$ Furthermore, although welfare state arrangements and social policies are increasingly being acknowledged as important determinants of health and of inequalities in health,,$^{3-8}$ there is little research into how gender differences in health vary by welfare state; specifically, there has been little gendered analysis with a focus on the implications for women. ${ }^{9-11}$

As part of the EUROTHINE project, this study focused on gender and health inequality in 13
European welfare states, representing four welfare state regimes: Finland, Sweden, Norway, Denmark, Holland, Ireland, England, Belgium, Germany, France, Italy, Portugal and Spain.

\section{GENDER INEQUALITIES IN HEALTH}

Over several decades, research on gender differences in mortality and morbidity has highlighted an important paradox. On the one hand, a wealth of evidence suggests that, in socioeconomically developed nations, men have shorter life expectancies than women. ${ }^{12}$ This gender difference is largest for violent causes of death ${ }^{13-16}$ and from early adulthood until middle age, ${ }^{16-19}$ but remains fairly stable throughout the life course. ${ }^{20}{ }^{21}$ On the other hand, women - in contrast to their lower mortality-actually report higher morbidity according to self-assessed indicators, including limiting long-term illness and self-assessed health (SAH). ${ }^{22}{ }^{23}$ Although some researchers have questioned the existence of this gender difference, ${ }^{24}$ most contemporary work suggests that the paradox is real, albeit smaller than previously thought. ${ }^{25-27}$

Traditionally, this paradox has been explained as the result of gender differences in the distribution of biological, behavioural or psychological traits. ${ }^{28}$ However, there remains some debate as to the best explanation for the paradox in actual mortality and $\mathrm{SAH}_{1}{ }^{22}{ }^{29}$ and it has been suggested that gender differences in mortality may differ between different socioeconomic groups or across countries.$^{30}$ It is therefore possible that gender differences in SAH may also vary by country or, indeed, welfare state type. In fact, evidence suggests that genderequitable social organisation reduces gender inequalities in both $\mathrm{SAH}^{31}$ and life expectancy. ${ }^{32}$

\section{WELFARE STATES, HEALTH AND HEALTH INEQUALITIES}

Welfare states are important determinants of health and health inequalities as they mediate the extent, and impact, of socioeconomic position on health. ${ }^{3-8}$ Welfare state provision varies extensively across the Western world but typologies have been put forward to categorise it into three, four or even five distinctive types or welfare state regimes. ${ }^{9}$ In terms of Europe, although a particular country's classification is often contested (eg, UK, Holland, Italy) and the quality of typologies questioned, ${ }^{9}$ a consensus is gradually emerging that there are four core welfare state regime types (see Ferrera ${ }^{33}$ and Bambra ${ }^{34}$ ): Social Democratic (Denmark, Norway, Sweden and, to a lesser extent, Finland and 
Holland); Corporatist (Belgium, France, Germany); Liberal (England, Ireland); and Southern (Italy, Spain, Portugal). Studies that have examined how health varies by welfare state regime have invariably all concluded that population health is enhanced, and (absolute though not relative) ${ }^{35}$ inequalities in health reduced, by the comparatively generous and universal welfare provision of the Social Democratic countries. ${ }^{3467}$

The mainstream comparative welfare state regime literature has only recently begun to seriously consider that the income redistribution, decommodification and other social effects of welfare state arrangements may vary by gender and that separate "gendered" typologies of welfare states may therefore be required. ${ }^{36}$ However, this debate has not yet filtered through to public health researchers and, to date, no studies have examined how gender differences in health vary by welfare state regime. ${ }^{9}$ Similarly, cross-national studies of inequalities in health have only recently begun to examine gender differences by welfare state type. ${ }^{10} 11$

It is worth noting that some studies have considered socioeconomic status as the basis of health inequalities between women and men, ${ }^{37-40}$ but this literature has tended to neglect the role of welfare state typologies. This body of work suggests that socioeconomic differences in SAH are found for both women and men, ${ }^{41}{ }^{42}$ although some authors have suggested that individual socioeconomic differences are less marked for women's health. ${ }^{43}{ }^{44}$ Other studies have reported significant interactions between women's health status and proxies of socioeconomic status, such as employment, marital status and housing tenure. ${ }^{45-50}$ However, with few exceptions, ${ }^{51}$ these studies have not tended to consider how socioeconomic position may be differentially related to the reported health of women and men in different countries or welfare state regimes.

In this context, this study is the first to examine the relationship between gender and $\mathrm{SAH}$ and the extent to which this varies by socioeconomic position in different European welfare states and to what extent this can be explained by welfare state regime theory.

\section{METHODS}

This study was conducted as part of the European Unionfunded "Tackling Health Inequalities in Europe (EUROTHINE)" project. The EUROTHINE project collated and harmonised data from various representative national health surveys of adults (aged $\geqslant 16$ ), carried out between 1998 and 2004. Sample sizes ranged from 7124 (Germany) to 118245 (Italy). Information on the individual country data sources are presented in table 1. Further information is available from the EUROTHINE website (www.eurothine.org).

SAH was measured using a five-point Likert-type scale ranging from "very good" health to "very bad" health. To maximise the efficiency of the analysis SAH was dichotomised to compare "bad and very bad health" with "average to very good health". Educational status was standardised across countries using the International Standard Classification of Education (ISCED), a four-point ranked scale with the lowest rank indicating the most educated (university/higher education) and highest rank the least educated (primary education and below). For the purpose of the current analysis, educational rank was used as a proxy for socioeconomic position.

Two descriptive analyses were conducted. The first explored the relationship between SAH and gender in each country, adjusting for age in years. The second stratified the analysis according to the four educational ranks. Logistic regression analysis was used for both analyses to obtain odds ratios summarising the relationship between SAH and gender (age adjusted). Men were the reference group for gender and for the outcome of SAH "average to very good health" was the reference.

\section{RESULTS}

The proportion of individuals indicating "bad and very bad" health varied between participating countries (see on line tables). For the majority the occurrence of poor health was less than $10 \%$; however, clear exceptions were Germany $(17.5 \%)$ and Portugal (25.9\%).

For all the countries, except Ireland, there was a significant relationship between gender and self-reported poor health $(p<0.05)$. England and Finland were the only countries to have a higher proportion of men reporting "bad and very bad" health relative to women. The remaining countries had a higher prevalence of self-reported poor health in women (see online tables). For all countries educational level was strongly related to self-reported poor health, with the least educated group reporting the highest levels of "bad and very bad" health.

Statistically significant differences in SAH by gender were observed for nine of the 13 European countries (table 2). In Denmark, Sweden, Norway, Holland, Italy, Spain and Portugal, a significantly higher proportion of women reported that their health was "bad" or "very bad" compared with men. The increased risk of poor SAH experienced by women from these countries ranged from a $23 \%$ increase in Denmark (odds ratio (OR) 1.23 ; 95\% confidence interval (CI) 1.08 to 1.39 ) to more than a twofold increase in Portugal (OR 2.01; 95\% CI 1.87 to 2.15). In the UK (OR 0.88; 95\% CI 0.78 to 0.99) and Finland (OR 0.85; 0.77 to 0.95$)$ men were significantly more likely to report "bad" or "very bad" health. There were no significant gender differences in $\mathrm{SAH}$ for Belgium, France, Germany and Ireland.

The relationship between gender and $\mathrm{SAH}$, stratified by educational rank, appeared to vary between the countries (figure 1). For Italy, Portugal and Sweden, the increased risk of poor SAH in women appeared to be greatest in the most educated group. For Denmark, Spain, Holland and Norway there was no clear relationship between the increased risk of poor SAH in women and educational level. The reduced risk of poor SAH in women from England was only statistically significant (borderline) for the least educated (table 2: OR 0.84; 95\% CI 0.71 to 0.99 ), whereas for women from Finland the only significant association between gender and SAH was among the most educated (see online tables: OR 0.86 ; $95 \%$ CI 0.78 to 0.95 ).

\section{DISCUSSION}

The results suggest that the relationship between gender and $\mathrm{SAH}$, and the extent to which it varies by socioeconomic position, does in fact differ across European welfare states. In the majority of cases, women reported worse health than men, and in some countries (Italy, Sweden, Portugal), these differences were most pronounced among the most highly educated. Some of the results (eg, for Portugal and Italy) can be explained by drawing on welfare state regime theory. ${ }^{33}{ }^{34} 52-57$ Other countries' findings (eg, UK or Finland) are more challenging to welfare state regime theory. Furthermore, the finding that gender differences in SAH are most prominent in the most educated groups in some countries requires further discussion.

\section{Confirming welfare state regime theory}

The fourfold typology of welfare states is very evident in our results: women who are moderately more likely to report "bad" 
Table 1 Information on data sources for each country (presented by welfare state regime) ${ }^{*}$

\begin{tabular}{lll}
\hline Country & Data source & Year(s) of survey \\
\hline $\begin{array}{l}\text { Social Democratic } \\
\text { Denmark }\end{array}$ & Danish Health and Morbidity Survey & 2000 \\
Finland & Finbalt Health Monitor & $1994,1998,2000,2002$, \\
& & 2004 \\
Holland & General social survey & $2003-2004$ \\
Norway & Norwegian Survey of Living Conditions & 2002 \\
Sweden & Swedish Survey of Living Conditions & $2000-2001$ \\
$\begin{array}{l}\text { Corporatist } \\
\text { Belgium }\end{array}$ & Health Interview Survey & \\
France & French Health, Health Care and Insurance & 2004 \\
& Survey & \\
Germany & German National Health Examination and & 1998 \\
& Interview Survey & \\
Liberal & & \\
England & Health Survey for England & 2001 \\
Ireland & Living in Ireland Panel Survey & $1995-2002$ \\
Southern & & \\
Italy & Health conditions and use of health services & $1999-2000$ \\
Portugal & National Health Survey & 2001 \\
Spain & National Health Survey & 2001 \\
\hline
\end{tabular}

*Source: www.eurothine.org.

or "very bad" SAH are those in the Social Democratic countries of Denmark, Holland, Norway and Sweden; women in the Southern regime countries of Portugal and Italy (and to a lesser extent Spain) are highly likely to report worse SAH; whereas those countries in which there appear to be no gender differences in SAH are the Corporatist countries of Belgium, France and Germany.

The only exceptions to this are Finland, England and Ireland. In welfare state regime theory, Finland is something of a hybrid case, with some typologies placing it in the Social Democratic regime ${ }^{33}$ while others place it in the Corporatist ${ }^{53}$ welfare state regime. This is perhaps a reflection of the shorter history of the welfare state in Finland (which was not developed until the 1970s) compared with the other Nordic welfare states. England and Ireland are almost always placed together in the Liberal regime type.

Welfare state regime theory is therefore able to provide some insight into how the countries analysed have grouped in terms of gender differences in SAH. However, although the high levels of "bad" or "very bad" SAH among women in the Southern regime countries reinforces research into gender and welfare states regimes, which has long highlighted the lack of support for women and their low economic and political participation in these countries, ${ }^{58}$ the results for the other regime types is less easy to explain through reference to this literature.

\section{Challenging welfare state regime theory}

Research into population health differences across welfare states has tended to find that health is better in the Social Democratic countries. . $^{3-8} 5758$ Furthermore, these welfare states are widely seen as the most progressive in terms of gender equality. ${ }^{36} 545558-61$ So the expectation would therefore be that gender differences in SAH would be comparatively smaller in the Social Democratic countries. However, this was not the case in our study. One possible explanation is that the mechanisms at play in terms of gender and health cannot be overcome by the traditional Social Democratic welfare interventions of income redistribution and extensive public service provision alone. ${ }^{8}$ Indeed, some feminist critiques have suggested that such policies have actually transferred women's economic dependency
Table 2 ORs and 95\% Cls for the association of gender with the risk of reporting bad or very bad self-assessed health compared with regular, good or very good selfassessed health*

\begin{tabular}{ll}
\hline & \multicolumn{1}{l}{ Total } \\
\cline { 2 - 2 } & OR (95\% CI) \\
\hline $\begin{array}{l}\text { Social Democratic } \\
\text { Denmark }\end{array}$ & $1.23(1.08$ to 1.39$)$ \\
Finland & $0.85(0.77$ to 0.95$)$ \\
Holland & $1.44(1.29$ to 1.60$)$ \\
Norway & $1.51(1.23$ to 1.87$)$ \\
Sweden & $1.23(1.06$ to 1.44$)$ \\
Corporatist & \\
Belgium & $1.09(0.94$ to 1.27$)$ \\
France & $1.15(0.95$ to 1.38$)$ \\
Germany & $1.13(1.00$ to 1.29$)$ \\
Liberal & \\
England & \\
Ireland & $0.88(0.78$ to 0.99$)$ \\
Southern & $0.93(0.77$ to 1.12$)$ \\
Italy & \\
Portugal & \\
Spain & $1.33(1.27$ to 1.39$)$ \\
\hline *0Rs are age adjusted; men are the reference category for all \\
comparisons.
\end{tabular}

from the family to the state-from private to public patriarchy. ${ }^{62}{ }^{63}$ Interlinked with this is the burden of the dual roles experienced by women in Social Democratic states. A high proportion of women work and, although public policy is progressive in terms of childcare and paternity leave, women are still responsible for the majority of domestic work and family care. $^{62}{ }^{63}$ Similarly, the suggestion has been made that the dualearner model leads to indirect discrimination against women as all women, even those very vocationally focused, are treated as potential mothers leading to women being put onto parallel "mommy career tracks". ${ }^{64}$ This may partly explain the high sexual segregation at work, and the gender pay gap in the Scandinavian countries that exists between men and women as opposed to between mothers and others as is the case in other Western countries. ${ }^{64}$ Perhaps another factor behind the results is the higher proportion of lone mothers in Social Democratic states ${ }^{65}$ who experience worse health than couple mothers. ${ }^{65}$ Of course, the English and Finnish results suggest that these relationships may not be consistent across all countries with high labour market participation by women. Further analysis using other measures of health (such as mortality data) would help to explore the consistency of this finding.

No significant gender differences in $\mathrm{SAH}$ were found in the Corporatist countries (Belgium, France and Germany), or in Ireland. The Corporatist welfare states are often considered to offer a contradictory set of policies and provisions in relation to women and the family. ${ }^{36} 5455$ 58-61 On the one hand, they provide some of the best provisions for women (eg, well-compensated and extensive maternity leave) whereas, on the other hand, they have much lower levels of labour market participation by women. ${ }^{36-61}$ The lack of gender difference in SAH could therefore reflect the fact that fewer women in the Corporatist countries experience dual roles. Similarly, there are lower levels of lone motherhood in the Corporatist countries (and Ireland). Conversely, the cases of Italy, Portugal and, albeit to a lesser extent, Spain caution that restrictive traditional gender roles for women can have an extremely adverse effect on gender differences in health. 
Figure 1 ORs and $95 \%$ Cls for the association of gender (stratified by educational rank) with the risk of reporting bad or very bad self-assessed health compared with regular, good or very good self-assessed health. ORs are age adjusted; men are the reference category for all comparisons.
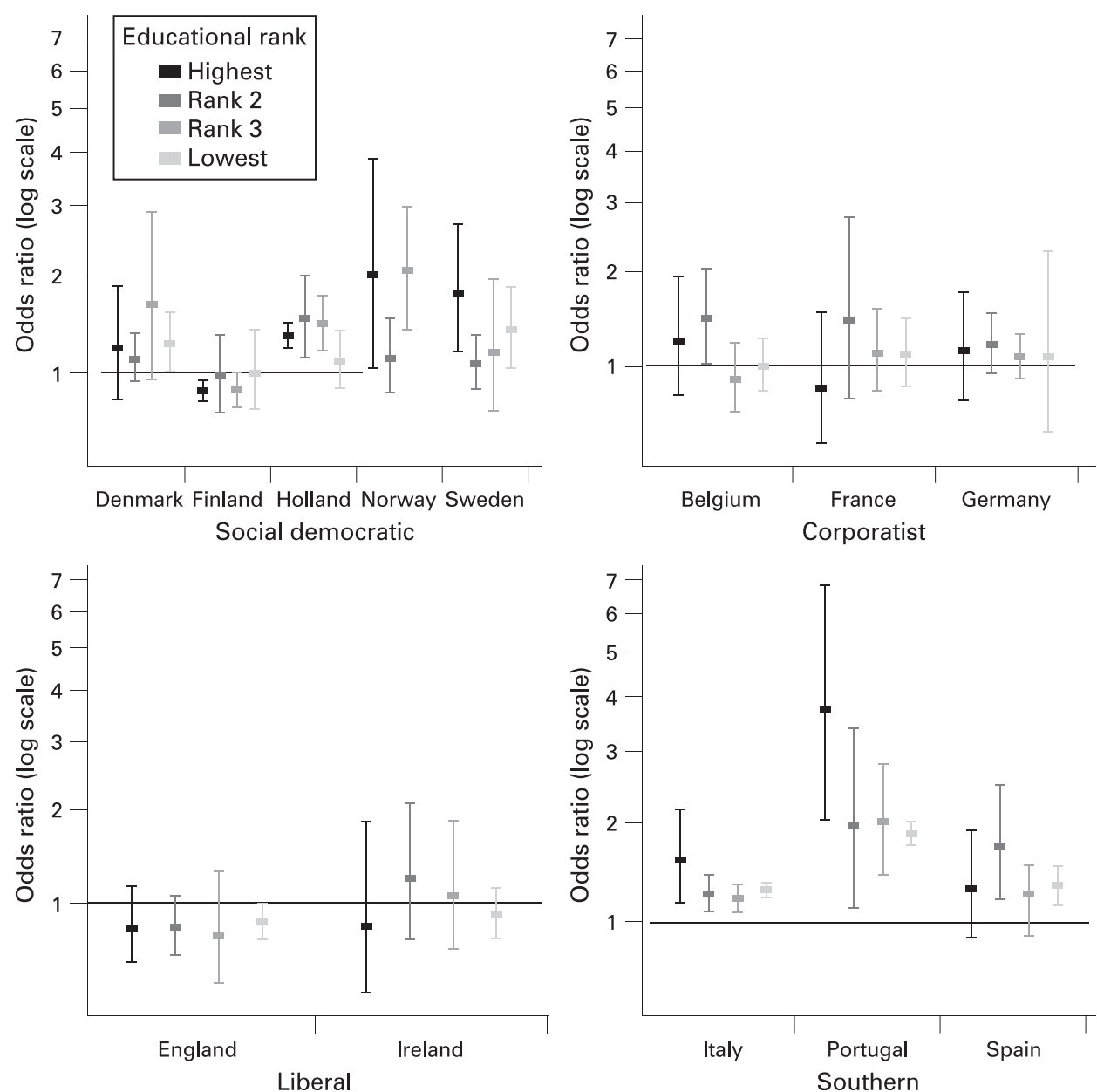

\section{Welfare state regimes and gender inequality in health}

In terms of gender differences in SAH stratified by educational rank, it is of note that there appears to be a stronger relationship in the most educated group for a number of European countries. For example, in the Southern regime countries of Italy and Portugal (but not Spain), the increased risk of poor SAH in women appeared to be greatest among the most highly educated. This may be a result of tensions between the traditional roles of women as wife and mother and the new pressures for women, particularly the most educated, to work. Indeed, there are large education-related differences in labour force participation among Southern European women; participation is generally higher among women of higher education, ${ }^{66}{ }^{67}$ whereas lower educated women generally assume more traditional role patterns ${ }^{66}$ and conform to the Mediterranean "male breadwinner model". ${ }^{6}$ Traditional cultural norms and corresponding state provision (minimal or no childcare support, etc, in part due to the later development of the welfare state) in the Southern regime countries therefore do not support these dual roles. ${ }^{68}$ The higher prevalence of smoking among more educated women in the Southern regime countries may also be a contributory factor. ${ }^{69}$

This was also the case in Social Democratic Sweden. However, in Finland, women in the highest group reported better SAH than men. In the other Social Democratic countries (Denmark, Holland and Norway), there was no clear relationship between the increased risk of poor SAH in women and educational rank. In England, the reduced risk of poor SAH reported by women was only among the least educated. Although it is possible to explain the higher rates of poor SAH among more educated women in terms of the pressures of these women's dual roles, the results are inconsistent and are therefore difficult to explain in a coherent way without further research.

\section{Policy implications}

Our results suggest that the nature of gender differences in health vary by country and to some extent by welfare state type. Therefore, achieving gender equity in health will require different policy responses in each European welfare state.

The results for the Social Democratic welfare states suggest that welfarist policies cannot adequately overcome genderbased inequities in health without accompanying changes at the cultural and societal levels. To start, we suggest implementing policies which target gender socialisation and traditional gender roles. A good example of such policies would be the recommendations of the Swedish Education Ministry's Delegation for Gender Equality in Preschool. ${ }^{69} 70$ The results for Italy and Portugal reinforce this suggestion, as the tension between traditional and modern roles experienced by women in these countries is detrimental to SAH.

The lack of gender differences in SAH in the Corporatist countries and our suggestion that this may be due to the existence of more dual couples and fewer dual roles for women implies that public policy interventions need to compensate more adequately for the lack of support experienced by lone mothers and by working women in general. Current state provision, even in the Social Democratic countries, has not yet adequately 
compensated for the detrimental health effects of lone parenthood, ${ }^{65}$ and the dual earner model may have unintended consequences for women such as gender segregation at work. ${ }^{64}$ This may require more extensive socialised childcare, as well as enhanced flexibility around working hours. There are some indications in our analysis that, in a variety of countries, the increased risk of poor SAH in women appeared to be greatest in the highest educational rank. This may also necessitate policy interventions to support women with dual roles.

\section{Strengths and limitations}

The EUROTHINE project provides the unique opportunity to compare gender differences in health across Europe using large, representative cross-sections of the adult population. Comparisons are made easier by the use of standardised classifications of important variables (eg, educational rank). However, national-level data cannot be used to make predictions at the level of the individual.

One limitation is the use of educational rank as a proxy for socioeconomic position. This relationship is unlikely to be uniform across all European countries. Furthermore, and of particular importance for this study, women's educational background may not be a very accurate indicator of their socioeconomic position. Indeed, research into socioeconomic inequalities in health among men and women have highlighted the sensitivity of the choice of indicator of socioeconomic position. ${ }^{2}$ A further issue concerns the possibility that within welfare regimes there could be direct, differential effects of different educational systems on gender inequalities in health.

Although SAH correlates well with other indicators of morbidity ${ }^{71}$ and is considered to be a good indicator to compare health across countries, ${ }^{72}$ it should be acknowledged that there may well be differences in reporting across countries, cultures, ethnicity, socioeconomic groups and, of course, by gender. ${ }^{73}$ It is also likely that there are variations in SAH between age groups, and different welfare state regimes will have policies that act differentially at various stages in the life cycle as well as by gender. For example, gender differences in health also differ by occupational characteristics ${ }^{74}$ and younger women may be more likely to live with their parents; occupation could therefore be an important confounding factor. ${ }^{75}$ Similarly, the institutionalisation of older people may vary by gender in different countries. Future research would benefit from examining SAH between different age groups (as well as the interaction between gender and other forms of social stratification such as ethnicity) to ascertain whether the patterns reported here vary by age as well as by welfare state regime and level of education.

Another possible limitation is our choice of welfare state regime typology. There are a multitude of competing welfare state regime typologies ${ }^{9}$ and, although there is no categorisation which has been generally accepted as the standard typology, the fourfold typology of Ferrera ${ }^{33}$ used in this paper has been highlighted as one of the most empirically accurate, ${ }^{34}$ at least in terms of how social benefits are granted and organised. However, if the typologies of other authors were used the results may have been different. For example, if the political traditions typology suggested by Navarro et a ${ }^{7}$ were utilised, the Christian Democratic group of countries (similar to Bismarckian regime) would include those with smaller gender inequalities (Germany, France) as well as those with higher gender inequalities (Italy). This needs to be taken into borne in mind when considering our results.

\section{CONCLUSION}

Current welfare regime theory clearly offers some explanatory insight into gender differences in health. However, until more work on the gendered nature of welfare states has been undertaken and is available for use by public health researchers, regime theory may not be as useful in examining gender and health as it has been in terms of overall population health. ${ }^{3-7}$ One obvious route to pursue relates to relationships between gender inequalities in health and gendered public policy indicators and typologies, such as the Gender Equity Index. ${ }^{76}$

\section{What is already known on this subject}

- International research has shown that different types of welfare states (welfare state regimes) are important determinants of health and health inequalities as they mediate the extent, and impact, of socioeconomic position on health.

- To date, however, no studies have examined how gender differences in health vary by welfare state regime. Similarly, there are few cross-national studies of inequalities in health which examine gender differences by welfare state type.

\section{What this study adds}

- The relationship between gender and self-assessed health varies by welfare state-in the majority of cases, women reported worse health than men.

- Women in the Social Democratic and Southern welfare states were more likely to report worse self-assessed health than men. In the Corporatist countries, there were no gender differences in self-assessed health. Findings were mixed for the Liberal regime countries.

- There was no consistent welfare state regime patterning for gender differences in self-assessed health by socioeconomic position. Although, in some countries (Italy, Portugal, Sweden), women's relatively worse self-assessed health tended to be most prominent in the group with the highest level of education.

\section{Policy implications}

- The policy implications of the study are that policies which target gender socialisation and traditional gender roles need to be implemented more extensively in all welfare state regimes.

- Traditional welfarist policies (eg, income redistribution) cannot adequately overcome gender-based inequities in health without accompanying changes at the cultural and societal levels. Policies which target gender socialisation and traditional gender roles, such as the recommendations of the Swedish Education Ministry's Delegation for Gender Equality in Preschool, may be beneficial in this regard.

- Public policy interventions need to compensate more adequately for the lack of support experienced by working women. This may require more extensive socialised childcare, as well as enhanced flexibility around working hours. 
Acknowledgements: We would like to thank all those involved in the EUROTHINE research collaboration (www.eurothine.org), particularly those involved in assembling the data set upon which this paper is based.

Competing interests: None.

\section{REFERENCES}

1. World Health Organization. World health statistics. Geneva: World Health Organization, 2001.

2. Ostlin P. Gender perspective on socioeconomic inequalities in health. In: Mackenbach JP, Bakker M, eds. Reducing inequalities in health: a European perspective. London: Routledge, 2002.

3. Bambra C. Health status and the worlds of welfare. Soc Policy Society 2006;5:5362.

4. Chung $\mathbf{H}$, Muntaner $\mathbf{C}$. Welfare state matters: a typological multilevel analysis of wealthy countries. Health Policy 2007;80:328-39.

5. Coburn D. Beyond the income inequality hypothesis: class, neo-liberalism, and health inequalities. Soc Sci Med 2004;58:41-56.

6. Dahl E, Fritzell J, Lahelma $\mathrm{E}$, et al. Welfare state regimes and health inequalities. In: Siegrist J, Marmot M, eds. Social inequalities in health. Oxford: Oxford University Press, 2006:193-222

7. Navarro V, Borrell C, Benach J, et al. The importance of the political and the social in explaining mortality differentials among the countries of the OECD, 1950-1998. Intl J Health Serv 2003;33:419-94.

8. Navarro V, Muntaner C, Borrell C, et al. Politics and health outcomes. Lancet 2006;368:1033-7.

9. Bambra C. Going beyond the three worlds of welfare: regime theory and public health research. J Epidemiol Community Health 2007;61:1098-102.

10. Lahelma $\mathbf{E}$, Arber $\mathbf{S}$. Health inequalities among men and women in contrasting welfare states: Britain and three Nordic countries compared. Eur J Pub Health 1994:4:213-26.

11. Rahkonen $\mathbf{0}$, Arber S, Lahelma E, et al. Understanding income inequalities in health among men and women in Britain and Finland. Int J Health Sci 2000;30:27-47.

12. United Nations. Sex differentials in life expectancy and mortality in developed countries. Popul Bull United Nations 1998;25:65-106.

13. Koskinen S, Martelin T. Why are socioeconomic mortality differentials smaller among women than among men? Soc Sci Med 1994;38:1385-96.

14. Koskinen S, Martikainen P, Martelin T, et al. Convergence of life styles and trends in sex mortality ratio among the middle-aged in Finland. Yearbook Popul Res Finland 1995;35:32-44.

15. Verbrugge LM. Sex and health: an update of hypotheses. J Health Soc Behav 1985;26:156-82.

16. Waldron I. Recent trends in sex mortality ratios for adults in developed countries Soc Sci Med 1993;36:451-62.

17. Martelin T. Differential mortality at older ages: sociodemographic mortality differences among the Finnish elderly. Helsinki: Publications of the Finnish Demographic Society, 1994

18. Vågerö $\mathbf{D}$. Health inequalities from the cradle to the grave? Hypotheses on health policy. Int J Health Sci 1992;3:175-83.

19. Valkonen T, Martelin T, Rimpelä A, et al. Socio-economic mortality differences in Finland 1981-1990. Helsinki: Statistics Finland, 1993.

20. Stillion J. Premature death among males, in men's health and illness. In: Sabo D Frederick Gordon D, eds. Sex, power and the body. London: Sage, 1995:46-67.

21. Waldron I. Contributions of biological and behavioural factors to changing sex differences in ischaemic heart disease mortality. In: Lopez A, Caselli G, Valkonen T, eds. Adult mortality in developed countries. Oxford: Clarendon Press, 1995:161-78.

22. Hunt K, Annandale E. Relocating sex and morbidity: examining men's and women's health in contemporary Western societies. Introduction to Special Issue on Sex and Health. Soc Sci Med 1999;48:1-5.

23. Wingard D. The sex differential in morbidity, mortality and lifestyle. Annu Rev Pub Health 1984;5:433-58.

24. Macintyre S. Sex differences in the perception of common cold symptoms. Soc Sci Med 1993;36:15-20.

25. Arber S, Cooper D. Sex differences in health in later life: the new paradox? Soc Sci Med 1999;48:61-76.

26. Lahelma $\mathbf{E}$, Rahkonen 0 . Health inequalities in modern societies and beyond. Soc Sci Med 1997;44:721-910.

27. Macintyre S. Sex differences in longevity and health in Eastern and Western Europe. In: Platt S, Thomas H, Scott S, Williams G, eds. Locating health: sociological and historical explanations. Aldershot: Avebury, 1993:57-74.

28. Verbrugge LM. The twain meet: empirical explanations of sex differences in health and mortality. J Health Soc Behav 1989;30:282-304.

29. Case A, Paxson C. Sex differences in morbidity and mortality. Demography 2005;42:189-214.

30. Mackenbach JP, Kunst AE, Groenhof $F$, et al. Socioeconomic inequalities in mortality among women and men: an international study. Am J Pub Health 1999;89:1800-4.

31. Anson 0, Levenson A, Bonney D. Gender and health on the kibbutz. Sex Roles 1990;11:213-35.

32. Leviatan U, Cohen J. Gender differences in life expectancy among Kibbutz members. Soc Sci Med 1985;2:545-51.
33. Ferrera M. The southern model of welfare in social Europe. J Eur Soc Policy 1996;6:17-37.

34. Bambra C. Sifting the wheat from the chaff: a two-dimensional discriminant analysis of welfare state regime theory. Soc Policy Admin 2007;41:1-28.

35. Mackenbach JP, Kunst AE, Cavelaars AE, et al. Socioeconomic inequalities in morbidity and mortality in western Europe. Lancet 1997;349:1655-9.

36. Bambra C. Defamilisation and welfare state regimes: a cluster analysis. Int J Soc Welfare 2007;16:326-38.

37. Arber S. Comparing inequalities in women's and men's health: Britain in the 1990s Soc Sci Med 1997; 44:773-87.

38. Cooper H. Investigating socio-economic explanations for gender and ethnic inequalities in health. Soc Sci Med 2002;54:693-706.

39. MacIntyre S, Hunt K. Socio-economic position, gender and health: how do they interact? J Health Psychol 1997:2:315-34.

40. Bartley M. Health inequality: an introduction to theories, concepts and methods Cambridge: Polity Press, 2004.

41. Matthews S, Manor 0, Power C. Social inequalities in health: are there sex differences? Soc Sci Med 2004;48:49-60.

42. Arber S. Integrating non-employment into research on health inequalities. Health Soc Policy 1996;26:445-81.

43. Yuen $\mathbf{P}$, Machin D, Balarajan R. Inequalities in health: socio-economic differences in self-reported morbidity. Public Health 1990;104:65-71.

44. Stronks K, van de Mheen H, van den Bos J, et al. Smaller socioeconomic inequalities in health among women: the role of employment status. Int J Epidemiol 1995:24:559-68.

45. Arber S. Class, paid employment and family roles: making sense of structural disadvantage, gender and health status. Soc Sci Med 1991;32:425-36.

46. Artazcoz LC, Borrell C, Benach J. Gender inequalities in health among workers: the relation with family demands. J Epidemiol Community Health 2001;55:639-47.

47. Artazcoz L, Borrell C, Benach J, et al. Women, family demands and health: the importance of employment status and socio-economic position. Soc Sci Med 2004;59:263-74.

48. Borrell C, Muntaner C, Benach J, et al. Social class and self-reported health status among men and women: what is the role of work organisation, household material standards and household labour? Soc Sci Med 2004;58:1869-87.

49. Artazcoz L, Benach J, Borrell C, et al. Unemployment and mental health understanding the interactions among gender, family roles, and social class. Am J Pub Health 2004;94:82-8.

50. Artazcoz L, Artieda L, Borrell C, et al. Combining job and family demands and being healthy: what are the differences between men and women? Eur J Pub Health 2004; 14:43-8.

51. Lahelma $\mathbf{E}$. The myth of gender differences in health: social structural determinants across adult ages in Britain and Finland. Curr Sociol 2001;49:31-54.

52. Bambra C. Decommodification and the worlds of welfare revisited. J Eur Soc Policy 2006;16:73-80.

53. Esping-Andersen G. The three worlds of welfare capitalism. London: Polity, 1990.

54. Esping-Andersen G. Social foundations of post-industrial economies. Oxford: Oxford University Press, 1999.

55. Korpi W, Palme K. Faces of inequality: gender, class, and patterns of inequality in different types of welfare states. Soc Polit 2000;7:127-91.

56. Leibfreid S. Towards a European welfare state. In: Ferge Z, Kolberg JE, eds. Social policy in a changing Europe. Frankfurt: Campus-Verlag, 1992:245-79.

57. Navarro V, Shi L. The political context of social inequalities and health. Soc Sci Med 2001:52:481-91.

58. Siaroff A. Work, welfare and gender equality: a new typology. In: Sainsbury D, ed. Gendering welfare states. London: Sage, 1994.

59. Bambra C. The worlds of welfare: Illusory and gender blind? Soc Policy Society 2004;3:201-12.

60. Sainsbury D. Gendering welfare states. London: Sage, 1994.

61. Sainsbury D. Gender, policy regimes and politics. In: Sainsbury D, ed. Gender and welfare state regimes. Oxford: Oxford University Press, 1999.

62. Borchost A, Siim B. Women and the advanced welfare state: a new kind of patriarchal power? In: Showstack-Sassoon A, ed. Women and the State. London: Routledge, 1987.

63. Walby S. Theorising patriarchy. Cambridge: Blackwell, 1990

64. Orloff A. Feminism for a post-maternalist era: the gender equality project in Europe and America. Paper presented at the UK Social Policy Conference, Edinburgh, June 2008.

65. Whitehead M, Burstrom B, Diderichsen F. Social policies and the pathways to inequalities in health: a comparative analysis of lone mothers in Britain and Sweden. Soc Sci Med 2000;50:255-70.

66. Schoenmaeckers R, Lodewijckx E. Demographic behaviour in Europe: some results from FFS country reports and suggestions for further research. Eur J Popul 1999;15:207-40.

67. Rindfuss R, Bumpass L, St John C. Education and fertility: implications for the roles women occupy. Am Sociol Rev 1980;45:431-47.

68. Aassve AS, Mazzuco L, Mencarini L. Childbearing and well-being: a comparative analysis of European welfare regimes. J Eur Social Policy 2005; 15:283-99.

69. Pampel FC. Age and education patterns of smoking among women in high-income nations. Soc Sci Med 2003:57:1505-14. 
70. Delegationen för jämställdhet i förskolan. Jämställdhet i förskolan. http://www. regeringen.se/sb/d/6293/a/67288 (accessed 14 May 2007).

71. Cohen G, Forbes J, Garraway M. Interpreting self-reported limiting long-term illness. Br Med J 1995:311:722-4.

72. Robine R, Jagger C. Creating a coherent set of indicators to monitor health across Europe. Eur J Publ Health 2003;1:6-14.

73. Jürges H. True health vs response styles: exploring cross-country differences in selfreported health. Health Econ 2006;16:163-78.
74. Artazcoz L, Borrell C, Cortàs I, et al. Occupational epidemiology and work related inequalities in health: a gender perspective for two complementary approaches to work and health research. J Epidemiol Community Health 2007;61:ii39-ii45.

75. Artazcoz L, Borrell C, Benach J, et al. Women, family demands and health: the importance of employment status and socio-economic position. Soc Sci Med 2004;59:263-74.

76. Social Watch. Gender equity index, 2007. http://www.socialwatch.org/en/ avancesyRetrocesos/IEG/index.htm (accessed 6 Jun 2007). 